\title{
Performance de sujeitos falantes do Português e do Inglês no Test of Early Language Development ***
}

\author{
Performance of Brazilian Portuguese and English speaking subjects \\ on the Test of Early Language Development
}

\author{
Elisabete Giusti* \\ Débora Maria Befi-Lopes**
}

\begin{abstract}
*Fonoaudióloga. Doutora em Linguística e Semiótica Geral pela Faculdade de Filosofia, Letras e Ciências Humanas da Universidade de São Paulo. Endereço para correspondência: Av. Conego Manoel Alves, 782 - São Paulo - SP - CEP 13484-420 (e.giusti@uol.com.br).

**Professora Livre-Docente do Curso de Fonoaudiologia da Faculdade de Medicina da Universidade de São Paulo. Coordenadora do Laboratório de Investigação Fonoaudiológica em Desenvolvimento da Linguagem e suas Alterações.

***Trabalho Realizado no Laboratório de Investigação Fonoaudiológica em Desenvolvimento da Linguagem e suas Alterações do Curso de Fonoaudiologia da Faculdade de Medicina da Universidade de São Paulo.
\end{abstract}

Artigo Original de Pesquisa

Artigo Submetido a Avaliação por Pares

Conflito de Interesse: não

Recebido em 26.09.07.

Revisado em 10.10.07; 13.11.07;

22.02.08.

Aceito para Publicação em 22.02.2008.

\begin{abstract}
Background: application of an American early language test in Brazilian Portuguese-speaking subjects. Aim: to compare the performance of normal Brazilian Portuguese and American English-speaking subjects on the Test of Early Language Development - Third Edition (TELD-3). Method: participants of this study were 120 subjects of both genders, ranging in age from 2:00 to 7:11 years (20 subjects in each age range). Subjects were selected and tested individually by the researcher. A comparative analysis of the subjects' performances with that observed in English-speaking children was made. Results: the results indicated that Brazilian and American subjects presented similar performances until the age of 4:11 years. Portuguese-speaking children of 5, 6 and 7 years presented higher scores on the receptive subtest of Form A when compared to their American pairs. Portuguese-speaking subjects of 5 and 6 years presented lower scores on the expressive subtest of Form B when compared to their American pairs. Conclusion: the translation of diagnostic instruments that are already available in other languages can lessen the lack of such resources in countries where these instruments are not yet available. Furthermore, this practice can allow cross-cultural studies which are relevant for researches on child language and language disabilities. Key Words: Child Language; Evaluation; Diagnosis; Language Tests.
\end{abstract}

\section{Resumo}

Tema: aplicação de um teste americano de linguagem infantil em sujeitos falantes do Português Brasileiro. Objetivo: comparar a performance de sujeitos normais falantes do Português Brasileiro com os sujeitos falantes do Inglês Americano no Test of Early Language Development - Terceira Edição (TELD-3). Método: participaram deste estudo 120 crianças, com faixa etária de 2:00 a 7:11 anos, sendo 20 sujeitos por faixa etária, de ambos os sexos. Os sujeitos passaram por um processo de seleção e foram testados individualmente pela pesquisadora, em seguida foi realizada uma análise comparativa entre a performance dos falantes do Português e os falantes do Inglês. Resultados: os resultados indicaram que a performance dos sujeitos foi equivalente para a idade até 4:11 anos. Para 5, 6 e 7 anos no subteste receptivo da forma A, os sujeitos falantes do Português obtiveram pontuação mais alta do que a apresentada na referência americana. E para as faixas etárias de 5 e 6 anos no subteste expressivo, na forma B, a pontuação dos sujeitos falantes do Português foi menor do que a observada na referência americana. Conclusão: a tradução de instrumentos diagnósticos já disponíveis em outras línguas pode amenizar a carência em países que não dispõem destes recursos e, além disso, pode possibilitar estudos transculturais viabilizando a comparação dos achados das pesquisas nacionais com os das pesquisas internacionais, o que é bastante relevante para os estudos da linguagem na infância e dos quadros de alterações.

Palavras-Chave: Linguagem Infantil; Avaliação; Diagnóstico; Testes de Linguagem. 


\section{Introduction}

In international literature regarding early language evaluation, many authors emphasize the need for formal and objective tests to evaluate and identify deficits in the process of language acquisition and development (1-6).

The diagnosis of language impairment is based on formal tests, which must be statistically reliable and valid (7). A test must: evaluate the general linguistic abilities, as well as specific receptive and expressive abilities; provide normative information that allow comparisons among groups and among age ranges; identify abilities and difficulties; be useful to professionals specialized in evaluation as well as to language specialists; be administered in a short period of time, avoiding the child's and the examiner's fatigue; and include a significant normative sample.

Based on these fundaments, Hresko, Reid and Hammill (8) published the first edition of the Test of Early Language Development (TELD), a test for early identification of language development deficits designed for children from 2 to $7: 11$ years of age, that includes expressive and receptive language measures. The linguistic aspects assessed and incorporated to the test are: semantic, syntactic and morphological. The test is in its third edition, published in 1999 by Pro-Ed Inc. In 2006, it was published a Spanish version of the test (TELD-3:S), developed by the authors in partnership with Margarita Ramos and Jorge Ramos (9).

In the TELD-3 examiner's manual the authors invite clinicians and researchers who use the test to send a copy of their researches, along with suggestions for its improvement.

To date, no national references were found regarding studies using TELD-3 with Brazilian Portuguese (BP) speakers.

In Brazil, there's a lack of formal and objective tests for evaluation of early language development, making it difficult to establish precise diagnosis and consequently to define appropriate therapeutic conducts and intervention plans (10-11). Studies have shown that the translation of existing instruments from other languages is a valid way to soften the lack of diagnostic resources in the area (12-14).

Based on the cited literature, this study had the aim to compare the performances of normal BP-and American English-speaking (AE) subjects on TELD3. The hypothesis was that the scores obtained by BP speakers would be equivalent to the American reference of the test.

\section{Method}

Subjects

The subjects were 120 subjects in normal language development, with ages ranging from 2:00 to 7:11 years (20 subjects in each age range, 10 boys and 10 girls). Subjects were selected from a childcare center and a public school, both from Limeira (SP), Brazil. Data gathering procedures began only after the approval of the study by the Ethics Commitee for the Analysis of Research Protocols (CAPPesq - HCFMUSP, 236/04) and the signing of the consent form by the children's legal tutors.

In order to participate on the study, the subjects went through a selection process that followed inclusion and exclusion criteria. The exclusion criteria were: speech and language complaints by the institutions' caregivers, previous indication and/or enrollment in speech and language therapy or other specialization follow-ups that indicated possible developmental deficits.

The following inclusion criteria were considered: children indicated by the institutions' caregivers as adequate communicators for their respective age ranges. Age range and birthday of the subjects were also considered, so that the sample was balanced regarding months' variation. Subjects also had to present adequate performances in a speech and language screening procedure, carried out individually by the researcher.

\section{Material}

This study used the all the material provided with the original version of TELD-3 (7), in English, along with the BP version of the instrument. The procedures adopted for the translation followed the recommendations of Guillemin et al. (15) and Herdman et al. (16): direct translation, back translation and equivalence analysis.

It's important to emphasize that the authors of the original test and the editor of the instrument (Pro-Ed) were contacted prior to its acquisition, and authorization was given to the purposes of the present study, which is a fundamental aspect for this kind of researches.

\section{Description of TELD-3}

TELD was developed by W.P. Hresko, D.K. Reid and D.D. Hammill. It is a test for early identification of deficits in language development, used to verify 
receptive and expressive language abilities in children with ages ranging from 2:00 to 7:11 years. The average time for the procedures is thirty minutes. It comprises two subtests: receptive language and expressive language, respectively with 37 and 39 items. These items evaluate semantic, syntactic and morphological aspects.

TELD-3 has two equivalent forms (A and B), which is explained by the authors to be used alternatively, in cases of evaluation and reevaluation.

The raw scores are converted into an expressive language quotient, a receptive language quotient and a spoken language quotient, which is an indicator of general language abilities. Based of the quotients it is possible to classify the child's performance as: very superior, superior, above average, average, below average, poor and very poor. Moreover, based on the raw scores it is possible to determine the linguistic age of the tested child.

According to the authors, it is a test of easy application that can early identify children who are candidates for an intervention program. The test can also measure the evolution of children throughout the intervention process and might be used as instrument for scientific researches regarding language development.

Data gathering procedure

All subjects were assessed individually and the test took, in average, thirty minutes to be carried out. The procedure followed the instructions presented in the original examiner's manual. Subjects' responses were registered in the appropriate protocols. After that, the examiner verified the answers, calculated the score and classified the performance of each subject, also according to the original instructions of the test. Data were aggregated and statistically analyzed.

Data analysis

After the appropriate statistical treatment, a comparative analysis was carried out between the performances obtained by BP- and AE-speaking normally developing subjects. For the AE speakers, the normative scores available at the experimenter's manual of TELD-3 were considered.

The comparative analysis considered the following aspects:

1. Whether the values of Receptive Raw Score and
Expressive Raw Score (which correspond to the number of correct answers on the test) were related to the variable Chronological Age, that is, whether the values of raw score increase with age and whether this increase is proportional to the observed in English-speaking subjects;

2. Whether the values of Equivalent Age (which correspond to the linguistic age obtained on the test) correspond to the Chronological Ages of the subjects, and whether these values correspond to those obtained by English-speaking subjects;

3. Whether the percentual distribution of the classification obtained by BP speakers corresponded to the distribution obtained by AEspeaking subjects.

\section{Statistical analysis}

A descriptive analysis was carried out, in which were calculated the mean, median and standard deviation of the variables Raw Score and Quotient. The increase of the raw scores with age was analyzed and compared to the American reference. To confirm the results of the descriptive analysis, a classic regression analysis was carried out, in which regression models were adjusted, separately, for each form of the test and for the variables Receptive Raw Score and Expressive Raw Score, in function of age variation (expressed in months). Next, the Shapiro-Wilks test and a models diagnosis analysis were applied, and the results indicated that all models were well adjusted. For inferential analysis, it was fixed a significance level of 5\% in all tests and confidence intervals.

A percentual distribution was carried out, based on the mean score obtained by the BP-speaking subjects.

\section{Results}

The following dispersion graphics show the increase in the values of Raw Score with age and compared to the American reference.

Graphic 01 shows that the mean Receptive Raw Score increase by age intervals behaves similarly to the American reference. In Graphic 02, it's possible to observe that the mean Expressive Raw Score increase by age intervals also presents a pattern similar to the American reference, except for children over 60 months, who presented scores below the expected on the Form B of the test.

These results were confirmed in a regression analysis, in which regression models were adjusted separately for each form of the test, with confidence 
interval of $95 \%$.

Comparison between chronological age and equivalent age (linguistic)

The comparison showed that chronological and equivalent ages were correspondent until 60 months for both forms of the test. After that age, in the Form A, BP-speaking subjects had higher values of receptive equivalent age than the American reference.

In the expressive subtest, both age measures were also correspondent until 60 months ( $4: 11$ years) and, after that age, in the Form B, the values of expressive equivalent age were below the American reference.

Distribution of general classification on the test

The following table shows the general distribution of the classification obtained by BP speakers on TELD-3.
GRAPHIC 01: Dispersion of Receptive Raw Score $\mathrm{x}$ Age with the American reference curve.

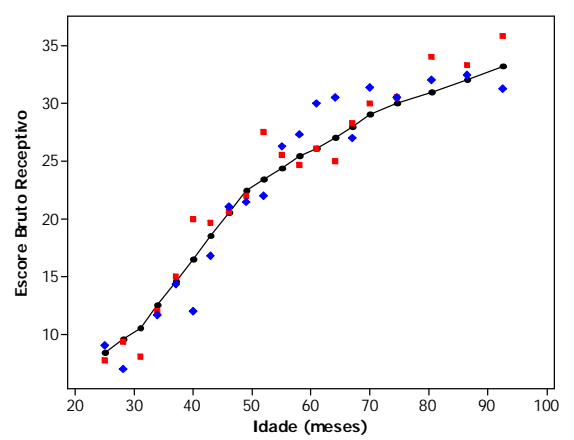

- Esperado
Forma
Forma B
Forma
GRAPHIC 02: Dispersion of Expressive Raw Score x Age with the American reference curve.

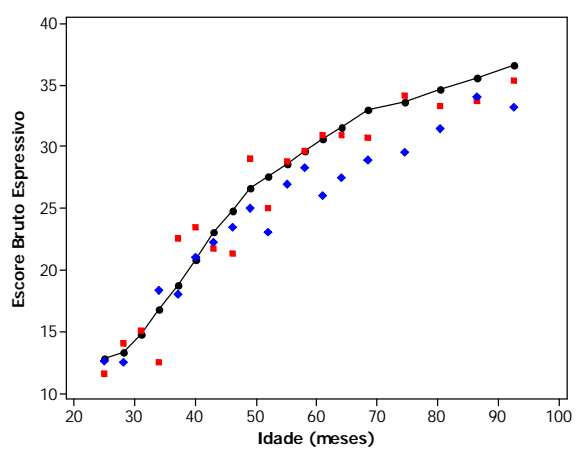

- Esperado
Forma
Forma B
Forma

TABLE 1. Distribution of the subjects' general classification on the test.

\begin{tabular}{cccc}
\hline Quotients* & Classification* & American subjects* & Brazilian subjects \\
\hline $131-165$ & Very superior & $2.34 \%$ & $0 \%$ \\
$121-130$ & Superior & $6.87 \%$ & $2.51 \%$ \\
$111-120$ & Above average & $16.12 \%$ & $13.58 \%$ \\
$\mathbf{9 0 - 1 1 0}$ & Average & $\mathbf{4 9 . 5 1 \%}$ & $\mathbf{6 9 . 7 3 \%}$ \\
$80-89$ & Below average & $16.12 \%$ & $14.18 \%$ \\
$70-79$ & Poor & 6.87 & $0 \%$ \\
$35-69$ & Very poor & $2.34 \%$ & $0 \%$ \\
\hline
\end{tabular}

Reference: TELD-3 examiner's manual, page 61 


\section{Discussion}

The aim of this study was to compare the performances of normally developing subjects, speakers of Brazilian Portuguese (BP), and American English (AE) speakers on TELD-3. The hypothesis for this comparison was that the scores obtained by BP-speaking subjects would be equivalent to the original references of the test.

Partially confirmed hypothesis.

The results showed that, until age $4: 11$, the performances of BP and AE speakers were equivalent and, beyond that age, BP-speaking subjects scored higher on the receptive subtest and lower on the expressive subtest, especially on the Form B of the test.

Hresko, Reid and Hammill refer that TELD-3 is an early identification test for language development impairments, and allows the assessment of generic aspects of children's language. This finding might indicate that, after age 4:11, differences between languages can be more evident, especially and possibly because of the focus on grammar acquisition (17).

The other criterion adopted in the comparison between Portuguese and English speakers' performances was to analyze the percentual distribution of the subjects' general classification. Table I showed that great part of the subjects was classified as "average" - $49.51 \%$ of English speakers and $69.73 \%$ of Portuguese speakers. The percentages of "below average" and "above average" subjects were also similar between groups. None of the Portuguese speakers were classified as "very superior", "poor" or "very poor".

In the American sample, different groups of subjects were included: Native Americans, Anglo European Americans, African Americans, Hispanic Americans, children with Learning Disabilities, children with Language Disorders, children with Attention Deficit/Hyperactivity Disorder and children with intellectual disabilities. In the Brazilian sample, only subjects with normal language development were included. Such difference between groups might explain why Portuguese speakers did not receive any "poor" or "very poor" classifications.

These results indicate that the test was effective to characterize the language performance of Brazilian Portuguese-speaking children. Similar findings were reported by Martinez (18), who tested Spanish-speaking children on TELD-3 and indicated that the test can be considered reliable to its purposes.

\section{Conclusion}

Based on the results presented, it's possible to conclude that TELD-3 - Brazilian Portuguese version was sensitive to characterize the language performance of the subjects of the present study. Regarding the receptive subtests, the results suggest that both forms (A and B) were sensitive to characterize the language performance of the sample. With respect to the expressive subtests, Form A was more effective for this purpose.

Further studies, with bigger samples and comparisons among different groups of subjects, are necessary in order to analyze the sensitivity and specificity of the test. Moreover, the use of the instrument with a bigger sample would contribute to the generalization of the present findings. The results might contribute to future studies focused on normal language development and early identification of language deficits, and also to transcultural researches, based in the comparison between national and international findings. The application of TELD-3 in different languages is important, as the test evaluates generic aspects of language development. 


\section{References}

1. Stark R, Tallal P. Selection of children with specific language deficits. Journal of Speech and Hearing Disorders. 1981;46:114-22.

2. Reed VA. An introduction to children with language disorders. 2nd edition. New York: McMillan; 1994.

3. Crespo-Eguílaz N, Narbora J. Clinical profiles and transitions in the spectrum of specific language impairment in childhood. Rev Neurol. 2003; 36(1):29-35.

4. Paul R. Principles of Assessment. In: Paul R. Second Edition. Language disorders from infancy through adolescence. St Louis: MO; 2001. p. 20-52.

5. Shipley KG, McAfee JG. Assessment in Speech-Language Patholoy: a Resource Manual. 3rd Edition. New York: Delmar Learning; 2004.

6. Ramirez $M$ et al. Fluidez verbal semantica en hispanohablantes: un análisis comparativo. Rev Neurologia, 2005; 41:463-8.

7. Hresko WP, Reid DK, Hammill DD. Test of Early Language Development (TELD) Third Edition. Austin, TX: PRO-ED; 1999.

8. Hresko WP, Reid DK, Hammill DD. Test of Early Language Development (TELD). Austin, TX: PRO-ED; 1981.

9. Ramos M, et al. Test of Early Language Development (TELD) Third Edition. Spanish. Austin, TX: PRO-ED; 2006.

10. Andrade CRF. A fonoaudiologia baseada em evidências. Einstein. 2004; 2:59-60.
11. Andrade CRF. Juste F. Proposta de análise de performance e de evolução em crianças com gagueira desenvolvimental. Revista Cefac. 2005;7(2):158-70.

12. Andrade CRF. Juste F. Aplicação de um teste americano de severidade da gagueira (SSI) em crianças fluentes falantes do Português Brasileiro. Pró-Fono Revista de Atualização Científica. 2001;13(2):177-80.

13. Duarte CS, Bordin, IAS. Instrumentos de avaliação. Rev Bras Psiquiatria, 2000; 22(2):55-8.

14. Mansur LL, et al. Teste de nomeação de Boston: desempenho de uma população de São Paulo. Pró-Fono Revista de Atualização Científica. 2006;18(1):13-20.

15. Guillemin F, Bombardier C, Beaton D. Cross-cultural adaptation of healthy-related quality of life measures: literature review and proposed guidelines. Journal Clinical Epidemiol. 1993;46(12):1417-32.

16. Herdman M, Fox-Rushby J, Badia X. A model of equivalence in the cultural adaptation of HRQoL instruments: the universalist approach. Qual Life Res. 1998;7:323-5.

17. Hadley PA. Assessing the emergence of grammar in toddlers at risk for specific language impairment. Semin Speech Lang. 2006;27(3):173-86.

18. Martinez L. Presentacion del PDIL (Prueba Del Desarrolo Inicial Del Lenguaje): Datos Normativos en Chile. In: Seminario Internacional Evaluações en Transtornos del Lenguaje. Santiago Chile; 2005. 